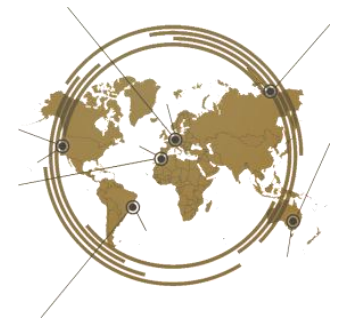

\title{
The students' language attitudes towards lecturers' code mixing: An SFL study
}

\author{
Marsandi Manar ${ }^{*}{ }^{1}$ Prapti Wigati Purwaningrum ${ }^{2}$ \\ ${ }^{1}$ English Literature Study Program, Universitas Bina Sarana Informatika, Indonesia \\ ${ }^{2}$ English Study Program, Universitas Bina Sarana Informatika, Indonesia
}

As the effort to have the insight into the existing status of a local language in Indonesia, especially in the academic setting viewed as the respected discourse, this current study aims to delineate the attitudes of millennial students towards lecturers' code mixing to Sundanese during courses. 42 responses reflecting respondents' perspectives towards the issue were collected via a qualitative questionnaire. To reveal the view of participants on the issue under the context of higher education, responses in the forms of 62 clauses were analysed by the transitivity framework of Halliday and Matthiessen. The findings of this SFL study shows that lecturers' code mixing to Sundanese during courses were viewed by $74 \%$ of Sundanese and non-Sundanese participants in positive ways while the rest addressed it with negative attitudes. The positive attitudes were respectively represented in material, mental, relational, and existential processes while the negative attitudes were constructed sequentially in relational, material and mental, verbal, and existential clauses. The main reasons in the positive attitudes as revealed by the transitivity analysis are associated with the need to maintain and preserve local language especially Sundanese via the academic channel.

Keywords: Attitudes, Millenials, Code Mixing, Sundanese, SFL

\section{INTRODUCTION}

OPEN ACCESS

ISSN 25033492 (online)

${ }^{*}$ Correspondence: Marsandi Manar

Marsandi.mnd@bsi.ac.id

Received: 21th April 2021 Accepted: 9 th October 2021 Published: 12th October 2021

Citation: Manar, M. and Purwaningrum, P.W. (2021). The students' language attitudes towards lecturers' code mixing: An SFL study.

J. Eng. Educ. Society. 6:2.

doi:10.21070/jees.v6i2.1646
It has been known that Indonesia with its above-average cultural diversity has over 700 local languages spread from islands to islands. The numbers of local languages in Indonesia reach 706 (Lewis et al., 2008, cited in Ewing, 2014) while Hasibuan et al. (2018) in his background of study points out that based on the data of Indonesian Language Centre in 2008 there are 746 native languages spread in the archipelagos. It has been commonly recognized that local languages serve not only as inherited identity and cultural treasure but also as a preserver maintaining systems, beliefs, ways of life, and many others in the society. The loss of local languages may trigger the disappearance of these properties especially ideology embedded in a society. To the present time, the existence of certain local languages in Indonesia has been approaching the in-danger status due to various factors such as government policy, cross cultural marriage, native speaker's attitude towards the image of their language, and many others. The study of Ewing (2014) has proved that even the popular local language like Javanese with native users surpassing 80 million is facing onslaught. The study has further reported that mothers in the middle-class society tended to avoid Javanese when speaking to their children for the expectation that their offspring were familiar with the national language used as the language medium for studying and working. 
Those mothers as the participants of the study believed that if their children have good communication skills in Indonesian then they will have good achievement in the academic world that will subsequently affect their success in the profession world after graduation. To conclude, the participants believed that to be accepted in a good job, their children must have good skills in Indonesian and this, to mention one, was done by not speaking their mother tongue to their children.

The phenomenon of shifting mother tongue or local language to another language especially national language in the family is also underpinned by Fitriati \& Wardani (2020) on their study scrutinizing the attitude of university students in Yogyakarta towards Indonesian, English, and local languages. The study found that although more than 90 per cent of participants addressed positive attitude to the preservation of local languages, most participants whose parents were native users of local languages in fact did not speak or did not have their ethnic language as their mother tongue. On the discussion of their study, it was interpreted by Fitriati \& Wardani (2020) that parents of students in their family tended to use and transfer national language instead of local language to their children. This even occurred with fathers and mothers coming from the same ethnic background. Again, one of the main reasons to avoid using local languages is due to academic and profession issues for future or career. As the result of certain factors, local languages in comparison with the national and international languages might be viewed not as salient as the two latters. This phenomenon of local languages facing the two moreinfluentially considered languages can lead to language shift even language loss for the long term especially in this virtual or cyber era where unlimited space and time for communication are available. Ideally it is expected that both local and national languages are viewed important, prioritized, and employed within their own area since both are the identity of Indonesia. This idealism again, to mention one, cannot be separated from people's attitude towards their languages.

Thus, figuring out how speakers or language users view their native language has become one of attempts to reveal the status of language existence in certain community or society. It is not denied that native users either as an individual or as a group have image on the languages that they or their environment speak. This is especially noticeably apparent in a multilingual society, for example, Indonesia. Indonesian people are commonly raised with local languages as their mother tongues and with the national language as their second language. This implies that Indonesian people in average are multilingual language users. This multilingualism may subsequently lead to the distinct attitude towards the image of different languages they speak.

Attitude can be viewed as "a feeling or opinion about something or someone, or a way of behaving that is caused by this" (Cambridge Dictionary, n.d.). If this definition of attitude is linked to language, then attitude towards language can be claimed as opinion addressed to certain languages.
Theoretically, language attitude is defined as "the attitudes which speakers of different languages or language varieties have towards each other's languages or to their own language" (Richards \& Schmidt, 2002). It is further argued that the attitude towards a language can be either positive or negative. (Richards \& Schmidt, 2002).

The attitude that native users address to their language may have possibility of affecting the sustainability of their languages. Positive attitudes towards their own local language can contribute to more sustainable existence of the language itself while negative attitude for various contexts may result in language shift even language loss in the long term. The library research conducted by Wulandari (2012) has claimed that negative attitudes addressed to certain languages especially ethnic languages are responsible for the phenomenon of language shift apart from the factors of language policy and language contact. It is also pointed out by Holmes (2012) that positive attitude towards language especially minority language can support its existence while the negative one may cause language shift. This indicates that as explained earlier the status of language existence can be previewed based on the attitudes that the native users put on their languages.

To the present time, there have been studies scrutinizing people's language attitudes towards certain languages. The study of Rahayu \& Wibowo (2018) investigating the perception and language attitude of South Lampung people towards the language use on Lampung Post has revealed that either the local, national, or international language was employed but in different portions. Among the thirty respondents in the study, most showed positive attitude towards the use of Indonesian language. The survey study also specifically showed that some respondents posed the necessity to incorporate local language especially certain terms into Lampung Post to promote its existence. Though being less-valued compared with the national language, the use of some terms of local language in Lampung Post is seen with positive views. This implies that South Lampung people have positive language attitude on their local language employed in least portion accompanying the national language in Lampung Post newspaper.

Another study scrutinizing peoples' attitude towards their ethnic languages was conducted by Deliana et al. (2017) on Minang Community in Medan. This questionnaire-major study revealed that overall participants from permanent and immigrant Minang citizens in Medan addressed positive attitude to their ethnic language. The study with its Holmes theory even found that positive attitude was addressed not only to the use of Minang language in informal contexts such as family and friendship, but also to that of formal situation. However, in terms of language choice between Minang, Indonesian, and other languages, the study specifically reported that respondents who were born and raised in Medan tended to choose Indonesian than their ethnic language for communication while the immigrant participants from Minang preferred to speak Minang instead of the former. 
Attitude towards ethnic language can also be viewed in relation with cross-cultural intermarriage phenomenon as found in the study carried out by Seli \& Kristi (2020) on Sumatran-Javanese families living in Lubuk Linggau South Sumatera. The qualitative study with questionnaire as the major instrument studied 100 participants and reported that children overall addressed negative attitude towards their parents' languages including Javanese. The children in general tended to choose Palembang Malay Lubuk Linggau dialect for the context of family and friendship while for public or formal domain such as religion, education, and employment they preferred to choose Indonesian. The study further claimed that the three most determining factors of the language choice were because of identity, environmental force, and working demands.

To date, most studies on the attitude towards local languages have been limited on the context outside academic setting. One of a few studies that indirectly related attitudes towards local language in the academic area is the study of Fitriati \& Wardani (2020) examining university students' attitudes towards Indonesian, English, and local languages. This quantitative questionnaire-based study, nevertheless, has not focused directly on examining participants' attitudes towards the use of local languages during academic courses. Further, previous studies of attitude towards language in general have tended to gather participants' responses without specific scrutiny on the linguistic features used as evidences. This study entitled 'Students' language attitudes towards lecturers' code mixing: An SFL study" hence employs SFL transitivity to delineate the insight into the language attitude especially of millennial student participants'.

Halliday \& Matthiessen (2004), SFL (Systemic Functional Linguistics) views language as a set of tools for meaning making based on the social contexts or purposes brought by texts. In a simple way, different texts of different contexts need different linguistic strategies and features. From the perspective of SFL, linguistic patterns and rules are not randomly selected and maneuvered but are suited to the function or goal brought by texts with their own distinct convention. One of meta-function of SFL refers to ideational aspect especially experiential meaning realized in transitivity system. Based on its origin, "the system of transitivity construes the world of experience into a manageable set of process types" (Halliday \& Matthiessen, 2004). The processes representing experiences are realized in clauses completed with participants (animate and inanimate) and optional circumstances attached to the process (Martin et al., 1997).

In this current SLF transitivity study, the concept of language attitude is linked to existing status of Sundanese language in the academic setting especially when the language is used as code mixing apart from the use of Indonesian language. Code mixing based on Longman Dictionary of Language Teaching and Applied Linguistics is viewed as "a mixing of two codes or languages, usually without a change of topic" (Richards \& Schmidt, 2002). It is further pointed out by Richards \& Schmidt (2002) that this phenomenon of employing different languages within the same topic occurs commonly in the multilingual context. In the context of Sundanese language with its native speakers surpassing thirty million, for example, the language is sometimes code-mixed with Indonesian language especially when it is used for multilingual classroom contexts.

Based on the general as well as empirical background and reviews above, this SFL-transitivity study aims to answer:

1) What language attitudes do millennial students address towards lecturers' code mixing to Sundanese during courses?

2) What meaning making is represented in the positive and negative attitudes towards lecturers' code mixing to Sundanese during courses?

\section{METHODS}

This qualitative SFL study investigating the language attitudes of millennial students towards lecturers' code mixing to Sundanese during courses applied Hallidayan transitivity system as the unit of analysis. The participants in this study are millennial university students studying in Bandung. Millennial generation or generation $\mathrm{Y}$ based on the American Psychological Association (2014) were born in the 1980s and 1990s. Millennial can also be defined as "born in the 1980s, 1990s, or early 2000s" (Cambridge Dictionary, n.d.). Millennial generation is also addressed to those born from early 1980s, mid 1990s, and early 2000s (Barr, 2020). This generation is characterized by high education level, above- average literacy in technology, and high familiarity with social media (Deal et al., 2010; Hershatter \& Esptein, 2010; Kowske et al., 2010).

For the data of this SFL-transitivity study, responses of 42 millennial student participants were gathered and analysed based on clauses. 22 Sundanese millenial students and 20 non-Sundanese (Aceh, Batak, Bugis, Minang, Javanese, Malay, and Sasak) participated in completing and sending back the questionnaire responses. This number of 42 participants is beyond the expectation of researchers.

The answers along with the questions in this questionnaire- based study were stated in Indonesian. Prior to this, the theory for classifying of language attitudes as proposed by Holmes (2012), namely positive or negative was employed in formulating the questionnaire questions. The closed-ended questions asked whether millennial student participants agreed or disagreed with the phenomenon of lecturers' code mixing to Sundanese during courses. Participants who agreed with lecturers' code mixing to Sundanese during courses were subsequently asked to rate the ideal adoption of Sundanese in percentage in comparison to Indonesian language. This phase was followed with openended questions asking participant's most main reason behind their agreement or disagreement. Further, all clauses derived from responses with positive and negative attitude were analysed into certain type of process followed with the 
analysis on the types of participants and circumstances. This step was executed by adapting the transitivity analysis table of Halliday \& Matthiessen (2004).

\section{RESULTS AND DISCUSSION}

The general purpose of this study is to reveal the attitudes of millennial students towards lecturers' code mixing to Sundanese during courses. Specifically, it aims to depict how the meaning making is represented in the attitudes of participants. Based on the findings of this SFL qualitative questionnaire study, of 42 millennial Sundanese and nonSundanese university students in Bandung, 31 participants or $74 \%$ addressed positive attitudes to lecturers' code mixing to Sundanese during courses, as long as the portion is less compared to the Indonesian language. Participants agreed that lecturers' use of Sundanese once at a time for accompanying the national language bring positive impacts. Even the majority of non-Sundanese participants agreed with the use of Sundanese as an addition to Bahasa Indonesia. In contrary, $26 \%$ or 11 participants (5 Sundanese and 6 non-Sundanese) addressed negative attitudes towards lecturers' code mixing to Sundanese during courses. Further details of participants' attitudes towards lecturers' code mixing to Sundanese during courses are provided in the following Table 1.

TABLE 1 | Participants' attitudes towards code mixing to Sundanese

\begin{tabular}{ccc}
\hline Participants & $\begin{array}{c}\text { Positive } \\
\text { attitude }\end{array}$ & $\begin{array}{c}\text { Negative } \\
\text { attitude }\end{array}$ \\
Sundanese & 17 & 5 \\
Non-Sundanese & 14 & 6 \\
Total & 31 & 11 \\
\hline
\end{tabular}

In terms of the ethnicity of participants, both Sundanese and non-Sundanese respondents have either positive or negative attitudes. In other words, there is no noticeable correlation between ethnicity and the tendency of responses. The majority of each group in both ethnics addressed lecturers' code mixing to Sundanese with positive attitude while the rest coming from both groups address it with negative attitude. For the portions of expected Sundanese to be employed in the classroom, in general, most participants agreed that the adoption of Sundanese by lecturers in the classroom should range from 10 to 20 per cent. This rate was gathered from open ended questionnaire questions without any predetermined scales by the researchers.

Based on the findings of the current SFL questionnaireresponse scrutiny on the process of meaning making in relational with the positive and negative attitudes, four types of processes (material, mental, relational, and existential) exist in the responses of positive attitudes, while in the responses containing negative attitude there are three verbal processes apart from the mentioned four categories of processes. The responses with positive attitude are mainly realised in the forms of material clauses followed with mental, relational, and verbal clauses respectively as provided in Table 2.

TABLE 2 | Process types in the positive and negative attitudes

\begin{tabular}{ccc}
\hline $\begin{array}{c}\text { Process } \\
\text { types }\end{array}$ & $\begin{array}{c}\text { Positive } \\
\text { attitude }\end{array}$ & $\begin{array}{c}\text { Negative } \\
\text { attitude }\end{array}$ \\
Material & 18 & 6 \\
Mental & 10 & 6 \\
Relational & 7 & 9 \\
Verbal & - & 3 \\
Existential & 2 & 1 \\
Behavioural & - & - \\
Total & 37 & 25 \\
\hline
\end{tabular}

In material clauses, 10 of 18 clauses represent the activities of promoting or sustaining local languages especially Sundanese. All goals in the 10 clauses represent Sundanese language ( 8 occurrences) and local language (2 occurrences). For the first participant, 9 of 10 actors are made elliptical or hidden. Other experiences apart from activities of language conservation deal with personal reasons such as increasing knowledge about Sundanese language, experience related with academic benefit in the classroom, and few miscellaneous experiences. The processes related with the activities of conserving local languages are realised by melestarikan (preserve), menjaga/mempertahankan (maintain), etc. One of those phenomena is depicted below.

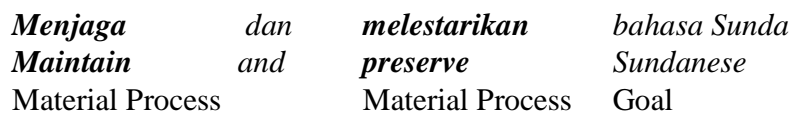

From the data of responses with negative attitudes, the occurrences of material clauses are in the second position in terms of frequency. 6 material clauses representing the negative attitudes, 3 are related with the experiences on academic or classroom matters while the rest is about general and personal experiences outside the classroom context. One of material clauses in the responses representing experiences on the academic context is shown in the following extract.

$\begin{array}{ll}\text { lebih meminimalisir } & \text { waktu pembahasan materi } \\ \text { tend to decrease } & \text { the time for discussing materials } \\ \text { Material Process } & \end{array}$

Material Process Goal

Further, in mental processes, of 10 mental clauses, 7 processes represent the experiences of understanding local language especially Sundanese, 2 mental experiences are related with academic benefit in the classroom and 1 deals with personal matter. Most second participants in the mental clauses represent Sundanese language as the phenomenon with elliptical sensers. The major processes of mental clauses found in the responses of positive attitudes belong to the cognitive aspect realised by mengenal/mengetahui (know), mempelajari (learn), ngerti (understand) dan kuasai (master) as exemplified below. 
Lebih mengenal

know

better

Mental Process

In reference to the data of responses with negative attitudes, mental clauses are equally distributed with material clauses. Among 6 mental clauses representing the negative attitudes, 5 are related with the negative experiences on academic or classroom matters while the rest is about personal experience outside the classroom context. All sensers in the academic experiences refer to students while all second participants (phenomenon) refer to Sundanese. One of mental clauses in the responses representing experiences on academic context is shown in the following extract.

\begin{tabular}{|c|c|c|}
\hline Tidak seтиа mahasiswa & memahami & \\
\hline Senser & Mental Process & Phenomenon \\
\hline
\end{tabular}

Third, for the processes of making relation, 4 of 7 clauses in the positive attitudes represent the general importance of knowing and learning Sundanese for individuals as realised in the attributes of suatu kepuasan tersendiri (a self-satisfying thing), penting (salient), unik pisan euy (very unique), and bentuk pembelajaran untuk memahami bahasa selain bahasa ibu (a way of learning on understanding other languages other than one's mother tongue). Further, 1 Relational clause in the positive attitudes builds on relation between the use of Sundanese and the instruction strategy for academic benefit while 2 clauses link the use of Sundanese to the strategy in language maintenance or conservation. One of clauses used to give attribution to conserving local language is given below.

$$
\begin{gathered}
\text { Carrier } \\
\frac{\text { Selingan }}{\text { penggunaan }} \\
\frac{\text { bahasa sunda di }}{\text { sela-sela }} \\
\text { perkuliahan }
\end{gathered}
$$

$\frac{\text { The use of }}{\text { Sundanese once }}$
$\frac{\text { at a time during }}{\text { lecturing }}$

Relational
Process
Merupakan

is

one of
strategies
in
preserving
the local
language.

From the data of responses with negative attitudes, the occurrences of relational clauses surpass other types of processes. 9 relational clauses representing the negative attitudes, the majority is related with the experiences on

academic or classroom matters while the rest is about personal experience outside the classroom context. Carriers in the academic experiences in general refer to students while the majority of attributes represent their cultural backgrounds. One of relational clauses in the responses relating students to their ethnic background is shown below.

\section{Karena tidak semua berasal dari suku sunda mahasiswa}

$\begin{aligned} & \text { Since } \\ & \text { student }\end{aligned}$
not every $\quad$ is $\begin{gathered}\text { from Sundanese } \\ \text { ethnic }\end{gathered}$
Carrier
Relational Process
Attribute

The last category of process found in the responses of positive attitude refers to existential clauses. One of two existential clauses in the data of positive attitudes is used to represent the existence of academic benefit and the other reveals the existence of general benefit of Sundanese words. The existential clause revealing the academic benefit is exemplified below.

\begin{tabular}{ll}
\multicolumn{1}{c}{ Ada } & sesi penyegaran ketika belajar \\
There is & a session of refreshing when learning. \\
Existential Process & Existent
\end{tabular}

On contrary, based on the data set of responses with negative attitude, the only one existential clause represents the existence of students coming from outside Sundanese background. This indicates negative stance towards lecturers' code mixing to Sundanese. The only-one existential clause in the negative-attitude response is given below.

$\begin{array}{cl}\text { There } \quad \text { are } & \begin{array}{l}\text { yang berasal dari luar suku Sunda. } \\ \text { ones coming from outside Sundanese } \\ \text { ethnic. }\end{array} \\ \text { Existential Process } & \text { Existent }\end{array}$

The last type of process found in the negative-attitude responses but is absent in the responses with positive attitudes is verbal clause or the process of saying experiences. In the former, 3 occurrences of employed verbal processes construe the saying activities in the classroom with lecturer as the sayer and academic utterances as the verbiage. This adoption of verbal clauses indicates the possibilities that lecturers' code mixing to Sundanese can cause academic drawbacks to students other than Sundanese. One of verbal clauses found in the negative-attitude responses is depicted below.

$\begin{array}{ll}\text { harus } & \text { kalimat yang tidak dimengerti oleh } \\ \text { mengulang } & \text { mahasiswa yang bukan suku Sunda. }\end{array}$

must repeat

Verbal Process sentences that are not understood by non-Sundanese students.

Verbiage 
Based on the findings of this current study, it has been reported above that around $74 \%$ of millennial participants addressed positive attitudes to lecturers' code mixing to Sundanese during courses. This phenomenon implies that millennial students with their traits of more-academic perspective, above-average literacy skills in IT, and high familiarity with social media are still aware of the importance of local languages.

Even the majority of non-Sundanese participants in this study addressed positive attitudes to Sundanese. This phenomenon of respect and awareness with other cultures apart from their own hints that millennial university students have good sense of unity. Most important, both Sundanese and non-Sundanese millennial student participants are sensitive to promoting local languages especially Sundanese. They are still aware of the struggling existence of local languages in the middle of national and international languages. The positive attitude of millennial student participants towards lecturers' code-mixing to Sundanese during courses in general also implies their stance for making use of academic discourse as one of medium for maintaining the existent of local languages especially Sundanese. Apart from the academic context, the study of Rahayu \& Wibowo (2018) investigating the perception and language attitude of South Lampung people towards the language use on Lampung Post have also reported that some participants of their study considered the use of locallanguage terms in the newspaper as way of promoting a native language in Indonesia.

Other previous studies on the attitude of native speakers towards local languages in Indonesia to some extent have also reported that local language users still view their ethnic language in positive ways but in terms of contexts other than academia. Most previous studies have not related the phenomenon of language attitudes with academic setting especially classroom context. One previous study that connects the academic context to students' attitude towards their native language refers to the investigation of Wagiati et al. (2017). The study with Sundanese teenagers as participants, however, delineates that the participants showed negative attitudes towards the use of Sundanese in schools. This phenomenon is different from the findings of the current study with university students as the participants. Nevertheless, the contradictory findings of this present study and that of Wagiati et al. (2017) cannot lead towards one holistic conclusion. In this current study, Sundanese is positioned only as a part of code mixing where its portion does not match the dominant adoption of Indonesian. In their study, the case refers to the use of Sundanese in general within school context.

Different with the study of Wagiati et al. (2017), the study of Wulandari \& Sundari (2012) on the case of students in pesantren (Islamic boarding school) reveals that participants had positive attitude towards the use of their Javanese native language at school context. It was specifically reported that pesantren students showed positive attitude to the adoption of Javanese by their teachers or Kiai. The study even notes that the student participants will possibly use Javanese as their language instructions when they become teachers in the pesantren. The findings of Wulandari \& Sundari (2012) at least support the result of the current study that the adoption of native languages in the academic context can be viewed with positive attitudes.

From the linguistic aspect, further findings of this SFL study have revealed that the distributed processes in the responses with positive attitudes are material, mental, relational, and existential respectively while those in the responses with negative attitudes contain relational processes in the first position, material and mental in the second place, verbal in the third and existential in the fourth rank. In the data set of positive-attitude responses, the processes of meaning making realized in the material, mental, relational, and existential clauses majorly establish the importance of preserving local languages especially Sundanese through the academic channel. In the negative-attitude responses, the processes of meaning making realized in relational, material, mental, verbal, and existential clauses give priority to the negative impact of using Sundanese on the academic aspect especially for non-Sundanese students.

The most noticeable distinct feature of meaning making processes between the responses of positive attitudes and those with negative attitudes is the distribution of material and relational clauses. The most frequent adoption of material clauses in the positive-attitude responses is in line with their function for making action meanings. As proposed by Halliday \& Matthiessen (2004), material clauses can establish concrete changes in an event. This concrete meaning serves to create impact in the form of action reflecting powerful experience. In the data set of positiveattitude responses, the major adoption of material instead of relational processes indicates the roles of using Sundanese in the academic channel for maintaining the language existence. Thus, there is a tendency to focus on taking action for sustaining Sundanese.

In another side, the most frequently used relational instead of material clauses in the data set of negative responses focus more on establishing connection between the millennial student participants and their non-Sundanese cultural or ethnic backgrounds. Because of these traits, the code mixing to Sundanese by lecturers might negatively affect their academic achievement. This representation is in line with the role of relational processes for establishing values. When experiences are symbolized in relational clauses, the perspectives addressed to an issue can be 
affected (Reath, 1998).

Millennial students' acceptance to welcoming lecturers' code mixing to Sundanese in this current study provides two distinct sides of interpretation. First, this phenomenon might reflect that Sundanese language is still considered as the prestigious native language with its sustainable status. As claimed by Wulandari (2012) in her library-based study, speakers' positive attitudes towards a language correlates with its status of sustainability. Another interpretation on millennial students' acceptance to welcoming lecturers' code mixing to Sundanese might be less optimistic as reflected in the process of meaning making. Since processes in the positive attitudes mostly represent the importance of action for language preservation, it can be interpreted that local languages in Indonesia including Sundanese might have encountered language shift in certain contexts. This suspected situation might have lead millennial academicians to think of academic setting as a way of protecting Indonesian local languages especially Sundanese.

The insight into the attitudes of millennial students towards the code-mixing to Sundanese during courses is expected to contribute to field of Sociolinguistics in Indonesia, especially to the issues of language policy. As it is known, in the bilingual even multilingual country, English functions as its foreign language while Indonesian in general serves as the second language after the local languages spoken as the mother-tongues of the overall society. It is expected that the academic setting viewed as the respected world can be a medium for the co-existence of national, international, and local languages.

\section{CONCLUSION}

The findings of this SFL questionnaire-response scrutiny reveal that the majority or $74 \%$ of millennial student participants in the study addressed positive attitudes towards lecturers' code mixing to Sundanese. Based on the transitivity analysis, the most frequently employed processes in the responses of positive attitudes refer to material clauses followed with mental, relational, and existential clauses. In the responses containing negative attitudes, processes of relation building appears in the highest number with equally distributed material and mental clauses in the second position, verbal experiences in the third place, and existential clause in the fourth rank. Material, mental, and relational clauses in the positive-attitude responses in general represent the importance of promoting and preserving local languages especially Sundanese via the academic channel. In the negative-attitude responses, overall the relational, material, mental, and verbal clauses hint the importance of effectively mastering academic content in the classroom by avoiding or challenging to use of Sundanese during courses.
Further, the highest occurrences of material processes in the positive-attitude responses indicate the importance of taking action to protect Sundanese language. This indirectly might imply that academic discourse community in higher education institutions has responsibility to maintain native languages especially Sundanese. In the negative-attitude responses, on the other hand, the most frequently used relational processes linking attributes of students to their cultural or ethnic backgrounds can be interpreted as a language strategy for increasing students' awareness towards their academic achievement. This possibly points out that academic discourse community in higher education institutions must be aware of its role as knowledge producer or academic building initiator.

A part from its findings, this study only made use of responses from 42 millennial student participants. It is assumed that the limited participants willingly to respond to the questionnaires in the present study were due to the demand to write open-ended answers. Further studies can employ larger numbers of participants and can involve participants under the contexts other than Sundanese language.

\section{ACKNOWLEDGEMENTS}

We would like to express our gratitude to the millennial university students who have participated in this study by writing and submitting their responses on-line. Further, in terms finance, this study was conducted with individual finance.

\section{REFERENCES}

American Psychological Association Association. (2014). Recent generations focus more on fame, money than giving back.

https://www.apa.org/news/press/releases/2012/03/fa me-giving

Barr, S. (2020, September 29). What generation do you belong to? millennial, generation $\mathrm{X}$ or $\mathrm{Z}$. Independent. https://www.independent.co.uk/lifestyle/generation-definitions-what-am-i-millennialgeneration-x-y-z-baby-boomers-golden-age-youngold-a8679741.html

Cambridge Dictionary (n.d). Attitude. In dictionary.cambridge.org. Retrieved March19, 2021, from

/https://dictionary.cambridge.org/es/diccionario/ingle s/attitude

Cambridge Dictionary (n.d). Millennial. In dictionary.cambridge.org. Retrieved March19, 2021, from

/https://dictionary.cambridge.org/es/diccionario/ingle s/millennial

Deal, J. J., Altman, D. G., \& Rogelberg, S. G. (2010). Millennials at work: What we know and what we need to do (If anything). Journal of Business and 
Psychology, 25, 191-199.

https://doi.org/10.1007/s10869-010-9177-2

Deliana, D., Ganie, R., \& Raswiy, N. (2017). Language attitude and choice by Minangkabau community: A Sociolinguistic study in Medan. Bahasa Dan Seni: Jurnal Bahasa, Sastra, Seni Dan Pengajarannya, 45(1), 76-85. https://doi.org/10.17977/um015v45i12017p076

Ewing, M. (2014). Language endangerment in Indonesia. International Journal of Education, 8(1), 12-22. https://doi.org/https://doi.org/10.17509/ije.v8i1.1764

Fitriati, A., \& Wardani, M. M. S. (2020). Language attitude and language choice among students in Yogyakarta. International Journal or Humanity Studies, 3(2), $112-117$.

https://doi.org/https://doi.org/10.24071/ijhs.v3i2.222 6.g1765

Halliday, M. A. K., \& Matthiessen, C. M. I. M. (2004). An introduction to functional grammar (3rd ed.). Hodder Headline Group.

Hasibuan, L. F., Gurning, B., \& Husein, R. (2018). Language attitude of Mandailingnese teenagers in desa Sidojadi kecamatan Bukit Malintang kabupaten Mandailing Natal. Linguistik Terapan, 15(2), 125134.

https://doi.org/https://doi.org/10.24114/lt.v15i2.12352

Hershatter, A., \& Esptein, M. (2010). Millennials and the world of work: An economist's perspective. Journal of Business and Psychology, 25, 211-223. https://doi.org/https://doi.org/10.1007/s10869-0109160-y

Holmes, J. (2012). An Introduction to Sociolinguistics (4th ed.). Pearson Education Limited.

Kowske, B. J., Rasch, R., \& Wiley, J. (2010). Millennials' (lack of) attitude problem: An empirical examination of generational effects on work attitudes. Journal of Business and Psychology, 25, 265-279. https://doi.org/10.1007/s10869-010-9171-8

Lewis, C. C., \& George, J. F. (2008). Cross-cultural deception in social networking sites and face-to-face communication. Computers in Human Behavior, 24(6), 2945-2964.

Martin, J. R., Matthiessen, C. M. I. M., \& Painter, C. (1997). Working with functional grammar. Arnold.

Rahayu, R., \& Wibowo, E. (2018). Persepsi dan sikap bahasa masyarakat Lampung Selatan terhadap penggunaan bahasa Indonesia di harian Lampung Post. Tuah Talino, 12(1), 57-71. https://doi.org/https://doi.org/10.26499/tt.v12i1.1100

Reath. (1998). The language of newspapers. Routledge.

Richards, J. C., \& Schmidt, R. (2002). Longman dictionary of language teaching and applied linguistics (3rd ed.). Pearson Education Limited.

Seli, S., \& Kristi, S. (2020). Language choice and attitude in Sumatran-Javanese intermarriage families in relation to language maintenance in Lubuklinggau. Journal of English Education Literature and Linguistics, 3(1), 116-130.

https://doi.org/https://doi.org/10.31540/jeell.v3i1.897
Wagiati, Riyanto, S., \& Wahya. (2017). Sikap berbahasa para remaja berbahasa Sunda di kabupaten Bandung : Suatu kajian sosiolinguistik. Metalingua, 15(2), 213221.

https://doi.org/http://dx.doi.org/10.26499/metalingua. v15i2.62

Wulandari, D. (2012). The importance of positive language attitude in maintaining Javanese language. In A. Subyanto, Mualimin, \& Prihantoro (Eds.), International Seminar Language Maintenance and Shift II (pp. 39-43). Universitas Diponegoro in collaboration with Balai Bahasa Jawa Tengah. http://eprints.undip.ac.id/54103/

Wulandari, D., \& Sundari, W. (2012). Sikap bahasa santri pada konteks pemertahanan bahasa Jawa dalam proses pengajaran di pesantren (Study pada pesantren-pesantren di kota Semarang) (0596/02304.2.16/13/2012).

Conflict of Interest Statement: The authors declare that the research was conducted in the absence of any commercial or financial relationships that could be construed as a potential conflict of interest.

Copyright (c) 2021 Marsandi Manar and Prapti Wigati Purwaningrum. This is an open-access article distributed under the terms of the Creative Commons Attribution License (CC BY). The use, distribution or reproduction in other forums is permitted, provided the original author(s) and the copyright owner(s) are credited and that the original publication in this journal is cited, in accordance with accepted academic prac- tice. No use, distribution or reproduction is permitted which does not comply with these terms. 